\title{
High risk human papillomavirus and Epstein Barr virus in human breast milk
}

\author{
Wendy K Glenn, Noel J Whitaker and James S Lawson ${ }^{*}$
}

\begin{abstract}
Background: Multiple viruses, including human immunodeficiency virus, Epstein Barr virus (EBV) and mouse mammary tumour virus have been identified in human milk. High risk human papillomavirus (HPV) sequences have been identified in breast cancer. The aim of this study is to determine if viral sequences are present in human milk from normal lactating women.

Findings: Standard (liquid) and in situ polymerase chain reaction (PCR) techniques were used to identify HPV and EBV in human milk samples from normal lactating Australian women who had no history of breast cancer. High risk human papillomavirus was identified in milk samples of 6 of 40 (15\%) from normal lactating women - sequencing on four samples showed three were HPV 16 and one was HPV 18. Epstein Barr virus was identified in fourteen samples (33\%).

Conclusion: The presence of high risk HPV and EBV in human milk suggests the possibility of milk transmission of these viruses. However, given the rarity of viral associated malignancies in young people, it is possible but unlikely, that such transmission is associated with breast or other cancers.
\end{abstract}

Keywords: Human papillomavirus, Epstein barr virus, Human milk

High risk human papillomavirus (HPV) is primarily considered as a sexually transmitted infection [1]. However, a range of other means of transmission have been documented. These include white blood cells [2] oral mucosa [3] intrauterine, placenta and cord blood [4]. High risk HPV type 16 has been identified in 4 to $8 \%$ of human milk samples [5,6]. On the other hand, in a recent study Mammas et al [7] did not identify any high risk HPV sequences in human milk from Greek women. Other means of HPV transmission in addition to sexually transmitted infections are important factors to be considered in the context of primary prevention of HPV by vaccines. We have become aware of recent, but unpublished experimental findings, that Epstein Barr virus (EBV) has the capacity to enhance the oncogenicity of HPV associated cervical cancer cells [8]. For this reason, in addition to HPV, we also investigated the presence of EBV in human milk samples.

Here we report the identification of high risk HPV types 16 and 18 plus Epstein Barr virus (EBV) in milk

* Correspondence: james.lawson@unsw.edu.au

School of Biotechnology and Biomolecular Sciences, University of New South Wales, Sydney, Australia from normal lactating Australian women. These findings have in part, been previously reported [9].

\section{Methods}

This project was formally approved by the University of New South Wales, Australia, Human Research Ethics Committee (HREC 05163). All participants gave written, informed, prior consent.

Samples of human breast milk were collected from 40 lactating Australian women. None of these women had a history of breast cancer. The milk was expressed into sterile $50 \mathrm{ml}$ falcon tubes. To prevent contamination, the milk samples were then transferred into $1.5 \mathrm{ml}$ eppendorf tubes using filtered tips for all procedures. The $1.5 \mathrm{ml}$ tubes were centrifuged at 2,000 rpm for 10 minutes. The whey and fat were removed and the pellet was washed twice with phosphate buffered saline (PBS). The pellet was then resuspended in $200 \mu \mathrm{l}$ of PBS. $10 \mu \mathrm{l} 1 \mathrm{M}$ Tris $\mathrm{pH} 8$ and $10 \mu \mathrm{l}$ of $0.5 \mathrm{M}$ ethylenediaminetetraacetic acid (EDTA) were added to 100ul of the PBS based solution, the mixture vortexed and $2 \mu \mathrm{l}$ $2 \%$ sodium dodecyl sulfate (SDS) and $1 \mu \mathrm{l}$ proteinase $\mathrm{K}$ (10mg per $\mathrm{ml}$ ) added. The tubes were heated at $55^{\circ} \mathrm{C}$
C Biomed Central

(c) 2012 Glenn et al.; licensee BioMed Central Ltd. This is an Open Access article distributed under the terms of the Creative Commons Attribution License (http://creativecommons.org/licenses/by/2.0), which permits unrestricted use, distribution, and reproduction in any medium, provided the original work is properly cited. 
for 1-3 hours, after which a phenol extraction followed by 2 chloroform washes were performed before an alcohol precipitation. The DNA pellet was resuspended in Tris-EDTA (TE) and checked with a $\beta$-globin PCR analysis. A reagent blank of bovine skim milk was used for each set of milk extractions.

DNA integrity was confirmed by standard PCR using $\beta$-globin primers G073 (5/-GAAGAGCCAAGGACAGG TAC-3/) and G074 (5/-CAACTTCATCCACGTTCACC3/). HPV screening used nested PCR with outer primers, PGMY, and inner primers GP as per Heng et al [10]. For EBV screening nested primers (EB3 5'-AAGGAG GGTGGTTTGGAAAG, EB4 5'AGACAATGGACTC CCTTAGC) and (EB1 5'-ATCGTGGTCAAGGAGGT TCC, EB2 5'-ACTCAATGGTGTAAGACGAC) were used as per Cinque et al [11]. The cycling conditions for the above PCRs were $95^{\circ} \mathrm{C}$ for $3 \mathrm{~min}$; followed by 35 cycles at $95^{\circ} \mathrm{C}$ for 30 seconds; $55^{\circ} \mathrm{C}$ for 30 seconds; $72^{\circ} \mathrm{C}$ for one minute and a final extension at $72^{\circ} \mathrm{C}$ for five minutes.

In situ PCR was attempted on a different set of milk samples. To prepare the milk samples for in-situ PCR, drops of the resuspended cell pellet in PBS were dried on glass slides followed by fixation in ice cold methanol for 5 minutes. An H\&E stain of the slides identified the milk samples which contained cells. Selected samples were treated with $0.1 \%$ triton $\mathrm{X}$ digestion for 10 minutes at room temperature. The primers used for HPV in situ PCR were the outer primers used for the HPV screening. $75 \mu \mathrm{L}$ of PCR mixture was prepared for each slide with the concentration of the reagents as follows: $7.5 \mu \mathrm{L}$ 10X PCR buffer (Roche Diagnostics), $0.375 \mu \mathrm{L}$ dNTP mixture (dATP, dGTP, dCTP; $25 \mathrm{mM} / \mathrm{ml}$ each), $0.33 \mu \mathrm{L}$ digoxigenin (DIG) - 11 - dUTP (25 nM, Roche Diagnostics), $6 \mu \mathrm{L}$ MgSO4 (100 mM, Roche Diagnostics),
$1 \mu \mathrm{L}(10 \mathrm{pM})$ forward primer and $1 \mu \mathrm{L}(10 \mathrm{pM})$ reverse primer, $1 \mu \mathrm{L}$ Taq Polymerase (Roche Diagnostics) and sterilized water. The thermocycling conditions were as follows: initial denaturation at $95^{\circ} \mathrm{C}$ for three minutes; 35 cycles at $95^{\circ} \mathrm{C}$ for one minute, $55^{\circ} \mathrm{C}$ for one minute and $72^{\circ} \mathrm{C}$ for one minute and a final extension at $72^{\circ} \mathrm{C}$ for five minutes.

\section{Findings}

Six of the forty milk samples (15\%) were positive for HPV. Sequencing of four samples showed three were positive for HPV type 16 and one was positive for HPV 18 (Figures 1 and 2). Some variations in the HPV 16 sequences were present. While mutations at bases 6689 and 6715 are common, the mutation at base 6657, although reported before in AF548851 to be Y, has not been found to be an A. The HPV 18 sequence was identical to AY 262282.

Fourteen of the 40 milk samples (33\%) were positive for EBV. Sequencing of two samples showed identical sequences to an EBNA 1 region of EBV strain B95-8. One of these samples was also positive for HPV 18.

In-situ PCR on a centrifuged milk sample showed high risk HPV in the nuclei of epithelial cells (Figure 3). There were differing amounts of cellular debris in each sample. Some appeared to contain no intact cells. The number of whole cells was very low and some were seen as clumps. The HPV positive cells seen in Figure 3 are from approximately $5 \%$ of the volume of a $1.5 \mathrm{ml}$ milk pellet. There were approximately $10 \mathrm{HPV}$ positive cells in the whole milk sample, no negative cells were observed. In-situ PCR was not performed on all the milk samples because of the low copy number of cells and large amounts of debris which were seen on the H\&E. In-situ PCR for EBV was not performed.

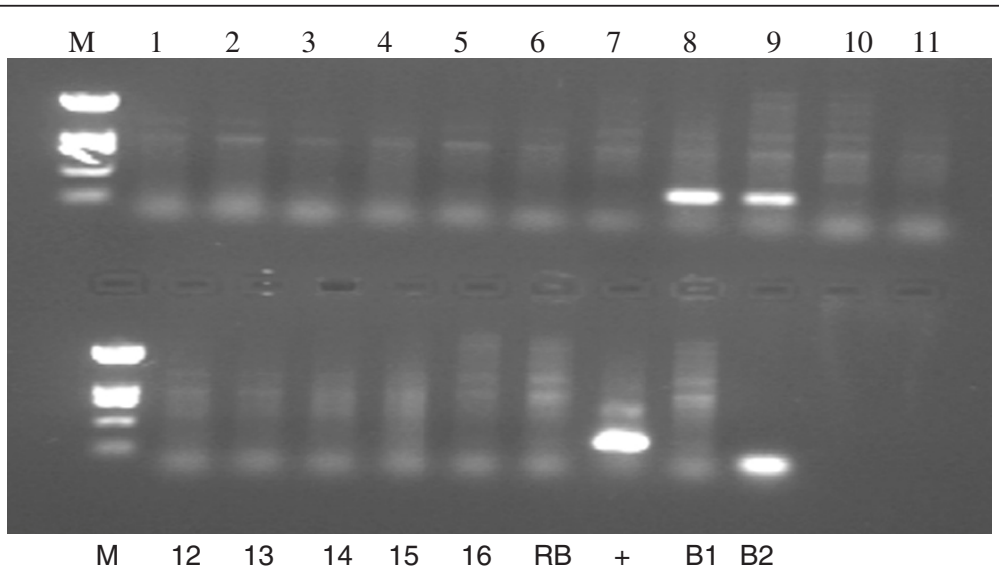

Figure 1 Outcomes of standard liquid PCR using HPV primers. 2\% agarose gel of Nested PCR products from breast milk samples. M=PuC Hinf 1 size standard (1,419 bp, 517 bp plus 396 bp, 214 bp, 75/65 bp). 1-40= samples (only 1-16 shown). RB = reagent blank. B1 =no DNA PCR blank after 2 round. B2 = no DNA PCR blank after 1 round. + = positive control (HeLa DNA). 


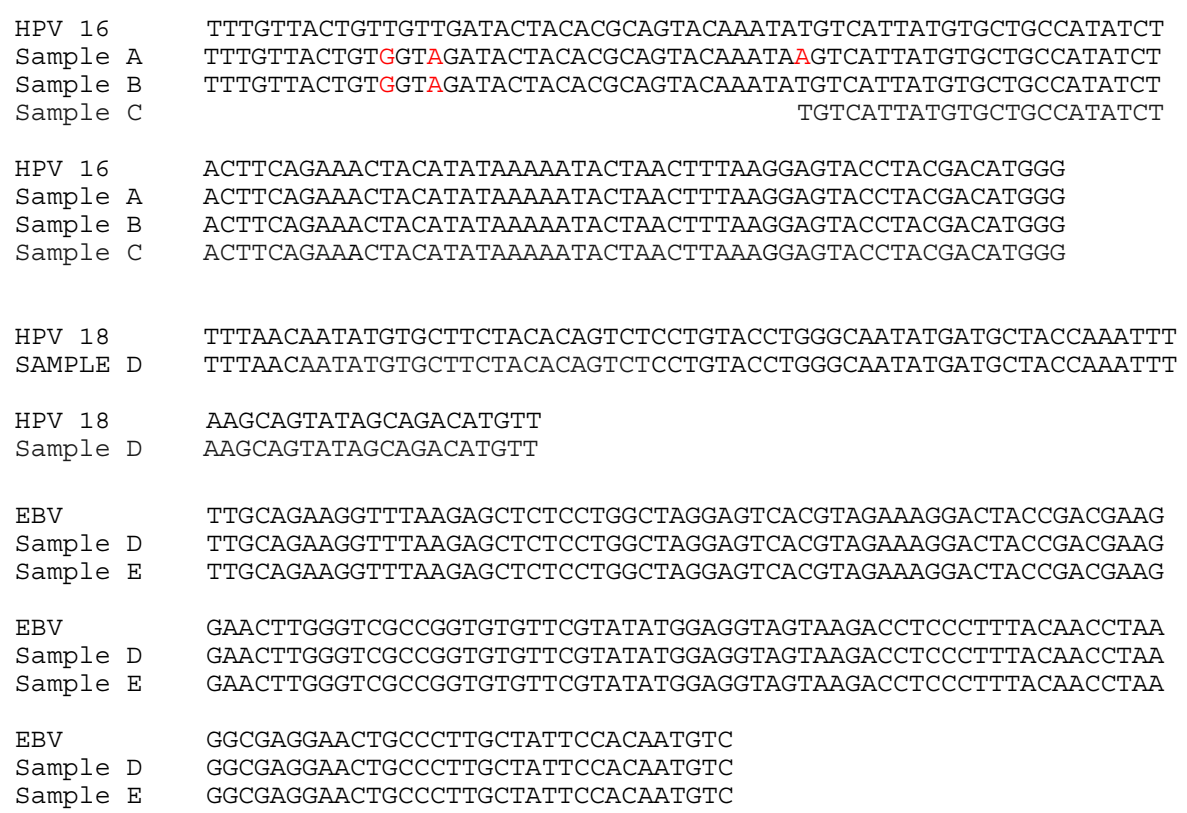

Figure 2 Sequencing results. Three HPV positive samples A,B,C compared to HPV 16 (FJ610151- bases 6627 to 6740) with differences shown in red, and one positive HPV sample D, compared to HPV 18 (AY262282). Samples C and D were only sequenced from one direction. Also sequences for two EBV positive samples D and E compared to V01555- (bases 109391- 109543). Note that Sample D was positive for HPV and EBV. Primer sequences have been omitted.

\section{Discussion}

We have demonstrated that both high risk HPVs and EBV may be present in the milk of a minority of normal lactating women, none of whom have had prior breast cancer. These findings are very similar to those of Sarkola et al [5] in Finland and Cazzaniga et al [6] in Italy and are in contrast to the negative findings of Mammas et al [7] in Greece.

Other viruses including human immunodeficiency virus (HIV), mouse mammary tumour virus and Epstein
Barr virus have previously been identified in human milk [12-14]. Transmission of each of these viruses by human milk to newborn infants is a possibility. Mother-to-child transmission of HIV-1 infection during exclusive breastfeeding in the first 6 months of life is a common occurrence in Africa [12]. It is also known that HPV can be transmitted from infected mothers to their newborn babies with persistence of the virus into childhood [15]. It is not known whether HPV transmission can be from infected human milk.
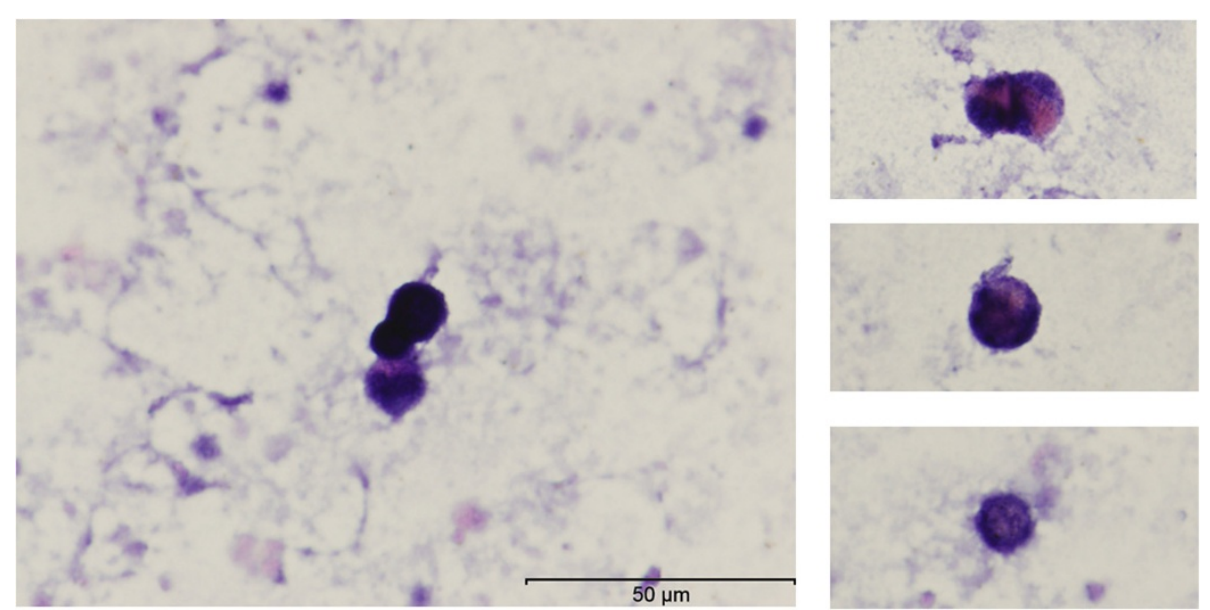

Figure $3 \mathrm{HPV}$ positive epithelial cell located in human milk by in situ PCR. The images on the right have been cropped to show cells only. Some cells can be seen as groups. Dark blue colour indicates the incorporation of Dig dUTP in the PCR. The negative control with no primers added (not shown) had no blue colour in the cells. 
High risk HPVs have been identified in both normal breast tissues and breast tumours of Australian women [10]. Therefore it is possible that HPV positive normal breast epithelial cells can be shed into the milk of normal lactating women.

The identification of viral sequences does not prove that these viruses are biologically active. The identification of HPV viral transcripts in human milk would be of future value. With respect to HPV such identification can indicate whether the HPV E6:L1 mRNA expression ratio is high (high E6 low L1) which is an indication that $\mathrm{HPV}$ is integrated and probably transforming, that is, the HPV is biologically active within the breast milk epithelial cells.

It is not known whether HPVs have long latency periods [16]. It is also unknown whether ingested HPVs can survive passage into the gut. HPVs are known to collaborate with Epstein Barr viruses which can have prolonged latency periods [8]. Therefore there are no current answers to the question whether HPVs and EBV ingested in infancy can lead to later oncogenicity.

\section{Abbreviations}

EDTA: Ethylenediaminetetraacetic acid; H \& E: Haematoxylin and eosin; HPV: Human papilloma virus; HIV: Human immunodeficiency virus; PBS: Phosphate buffered saline; PCR: Polymerase chain reaction; SDS: Sodium dodecyl sulfate; TE: Tris-EDTA.

\section{Competing interests}

There are no conflicts of interest for any of the authors.

\section{Author's contributions}

WKG: collection of milk samples, conduct of standard and in situ PCR, preparation of the manuscript. NJW: supervision and quality assurance of the laboratory work, preparation of the manuscript. JSL: conceptualisation, collection of milk samples, analysis of data, manuscript preparation. All authors read and approved the final manuscript.

\section{Acknowledgements}

Joy Heads collaborated with the authors for the collection of milk samples. We recognise the co-operation of the participating women who donated milk for this investigation.

Received: 30 April 2012 Accepted: 30 August 2012

Published: 1 September 2012

\section{References}

1. Kjaer SK, Chackerian B, van den Brule AJ, Svare El, Paull G, Walbomers JM, Schiller JT, Bock JE, Sherman ME, Lowy DR, Meijer CL: High-risk human papillomavirus is sexually transmitted;evidence from a follow-up study of virgins starting sexual activity (intercourse). Cancer Epidemiol Biomarkers Prev 2001, 10:101-116.

2. Chen AC, Keleher A, Kedda MA, Spurdle AB, McMillan NA, Antonsson A: Human papillomavirus: DNA detected in peripheral blood samples from healthy Australian male blood donors. J Med Virol 2009, 81:1792-1796.

3. Rautava J, Syrjänen S: Human papillomavirus infections in the oral mucosa. J Am Dent Assoc 2011, 142:905-914.

4. Syrjänen S: Current concepts on human papillomavirus infections in children. APMIS 2010, 118:494-509.

5. Sarkola M, Funtala M, Grenman S, Syganen S: Human papillomavirus DNA detected in breast milk. Ped Inf Dis J 2008, 27:557-558.

6. Cazzaniga M, Gheit T, Casadio C, Kahn N, Macis D, Valenti F, Miller MJ, Sylla BS, Akiba S, Bonnani B, Decensi A, Veronesi V, Tommasino M: Analysis of the presence of cutaneous and mucosal papilloma virus types in ductal lavage fluid, milk, and colostrum to evaluate its role in breast carcinogenesis. Breast Cancer Res Treat 2009, 114:599-605.

7. Mammas IN, Zaravinos A, Sourvinos G, Myriokefalitakis N, Theodoridou M, Spandidos DA: Can 'high-risk' human papillomaviruses (HPVs) be detected in human breast milk? Acta Paediatr 2011, 100:705-707.

8. Hagensee ME, Herrel N, D'Angelo A, Sutton K, Clark R, Cameron JE: Epstein Barr virus interacts with human papilloma virus to decrease apoptosis in vitro and increase cervical dysplasia in vivo. Trieste: International Centre Genetic Engineering Biotechnology DNA Tumour virus Meeting proceedings; 2011. Personal communication. Email for Jennifer Cameron: jcame2@lsuhsc.edu.

9. Glenn WK, Heng B, Whitaker NJ, Lawson JS: Letter to the Editor Reply: Koilocytes indicate a role for human papilloma virus in breast milk. $\mathrm{Br} \mathrm{J}$ Cancer 2010, 102:788-788.

10. Heng B, Glenn WK, Ye Y, Tran D, Delprado W, Lutze-Mann L, Whitaker NJ, Lawson JS: Human papilloma virus is associated with breast cancer. $\mathrm{Br} J$ Cancer 2009, 101:1345-1350.

11. Cinque $P$, Brytting $M$, Vago L, Castagna A, Parravicini C, Zanchetta $N$, D'Arminio Monforte A, Wahren B, Lazzarin A, Linde A: Epstein-Barr virus DNA in cerebrospinal fluid from patients with AIDS-related primary lymphoma of the central nervous system. Lancet 1993, 342:398-401.

12. Coovadia HM, Rollins NC, Bland RM, Little K, Coutsoudis A, Bennish ML, Newell M-L: Mother-to-child transmission of HIV-1 infection during exclusive breastfeeding in the first 6 months of life: an intervention cohort study. Lancet 2007, 369:1107-1116.

13. Johal H, Ford CE, Glenn WK, Heads J, Lawson JS, Rawlinson WD: Mouse mammary tumor like virus (MMTV) sequences in breast milk from healthy lactating women. Breast Cancer Res Treat 2011, 129:149-155.

14. Junker AK, Thomas EE, Radcliffe A, Forsyth RB, Davidson AGF, Rymao L: Epstein-Barr virus shedding in breast milk. Am J Med Sci 1991, 302:220-223.

15. Puranen MH, Yliskoski MH, Saarikoski SV, Syrjanen KJ, Syrjanen SM: Exposure of an infant to cervical human papillomavirus infection of the mother is common. Am J Obstet Gynecol 1997, 176:1039-1045.

16. Gravitt PE: The known unknowns of HPV natural history. J Clin Invest 2011, 121:4593-4599.

doi:10.1186/1756-0500-5-477

Cite this article as: Glenn et al:: High risk human papillomavirus and Epstein Barr virus in human breast milk. BMC Research Notes 2012 5:477.

\section{Submit your next manuscript to BioMed Central and take full advantage of:}

- Convenient online submission

- Thorough peer review

- No space constraints or color figure charges

- Immediate publication on acceptance

- Inclusion in PubMed, CAS, Scopus and Google Scholar

- Research which is freely available for redistribution 